\title{
Detection of anti-infliximab antibodies is impacted by antibody titer, infliximab level and IgG4 antibodies: a systematic comparison of three different assays
}

\author{
Joana Afonso, Susana Lopes, Raquel Gonçalves, Paulo Caldeira, Paula Lago, \\ Helena Tavares de Sousa, Jaime Ramos, Ana Rita Gonçalves, Paula Ministro, \\ Isadora Rosa, Ana Isabel Vieira, Rosa Coelho, Patrícia Tavares, João Soares, \\ Ana Lúcia Sousa, Diana Carvalho, Paula Sousa, João Pereira da Silva, Tânia Meira, \\ Filipa Silva Ferreira, Cláudia Camila Dias, Yehuda Chowers, Shomron Ben-Horin \\ and Fernando Magro on behalf Portuguese IBD Study Group (GEDII)
}

\begin{abstract}
:
Background: There is scant information on the accuracy of different assays used to measure anti-infliximab antibodies (ADAs), especially in the presence of detectable infliximab (IFX). We thus aimed to evaluate and compare three different assays for the detection of IFX and ADAs and to clarify the impact of the presence of circulating IFX on the accuracy of the ADA assays. Methods: Blood samples from 79 ulcerative colitis (UC) patients treated with infliximab were assessed for IFX levels and ADAs using three different assays: an in-house assay and two commercial kits, Immundiagnostik and Theradiag. Sera samples with ADAs and undetectable levels of IFX were spiked with exogenous IFX and analyzed for ADAs.

Results: The three assays showed $81-96 \%$ agreement for the measured IFX level. However, the in-house assay and Immundiagnostik assays detected ADAs in 34 out of 79 samples, whereas Theradiag only detected ADAs in 24 samples. Samples negative for ADAs with Theradiag, but ADA-positive in both the in-house and Immundiagnostik assays, were positive for IFX or IgG4 ADAs. In spiking experiments, a low concentration of exogenous IFX (5 $\mu \mathrm{g} /$ $\mathrm{ml}$ ) hampered ADA detection with Theradiag in sera samples with ADA levels of between 3 and $10 \mu \mathrm{g} / \mathrm{ml}$. In the Immundiagnostik assay detection interference was only observed at concentrations of exogenous IFX higher than $30 \mu \mathrm{g} / \mathrm{ml}$. However, in samples with high levels of ADAs ( $>25 \mu \mathrm{g} / \mathrm{ml}$ ) interference was only observed at IFX concentrations higher than $100 \mu \mathrm{g} /$ $\mathrm{ml}$ in all three assays. Binary (IFX/ADA) stratification of the results showed that IFX+/ADAand IFX-/ADAs + were less influenced by the assay results than the double-positive (IFX+/ ADAs+) and double-negative (IFX-/ADAs-) combination.

Conclusions: All three methodologies are equally suitable for measuring IFX levels. However, erroneous therapeutic decisions may occur when patients show double-negative (IFX-/ADAs) or double-positive (IFX+/ADAs+) status, since agreement between assays is significantly lower in these circumstances.
\end{abstract}

Keywords: anti-infliximab antibodies, anti-Infliximab antibody methodologies, infliximab trough levels, therapeutic drug monitoring

\section{Introduction}

Infliximab (IFX) is a chimeric (human-murine) monoclonal IgG1 anti-tumor necrosis factor alpha $(\mathrm{TNF}-\alpha)$ antibody used in the treatment of inflammatory bowel disease (IBD) [Bendtzen, 2013].
Although IFX has profoundly improved the treatment of inflammatory diseases, not all patients respond to induction therapy, and up to $50 \%$ of patients experience the loss of clinical response over time (secondary loss of response) [Yanai and
Ther Adv Gastroenterol 2016, Vol. 9(6) 781-794 DOI: 10.1177/ $1756283 \times 16658223$

(c) The Author(s), 2016 Reprints and permissions: http://www.sagepub.co.uk/ journalsPermissions.nav
Correspondence to:

Fernando Magro, MD, PhD Gastroenterology

Department, Medical

School, Centro Hospitalar

São João, Alameda Prof.

Hernâni Monteiro,

4200-319 Porto, Portugal

fmamed.up.pt

Joana Afonso, MSc

Filipa Silva Ferreira, MD

Department of

Pharmacology and

Therapeutics, Faculty of

Medicine, University of

Porto, Porto, Portugal

MedInUP, Centre for Drug

Discovery and Innovative

Medicines, University of

Porto, 4200 Porto, Portugal

Susana Lopes, MD

Rosa Coelho, MD

Patrícia Tavares, MD

Gastroenterology

Department, Centro

Hospitalar São João,

Porto, Portugal

Raquel Gonçalves, MD

João Soares, MD

Gastroenterology

Department, Hospital de

Braga, Braga, Portugal

Paulo Caldeira, MD

Ana Lúcia Sousa, MD

Gastroenterology

Department, Centro

Hospitalar do Algarve,

Faro, Portugal

Paula Lago, MD

Gastroenterology

Department, Centro

Hospitalar do Porto, Porto, Portugal

Helena Tavares de Sousa, MD

Gastroenterology

Department, Centro

Hospitalar do Algarve,

Portimão, Portugal

Departament of Medicine

e Medical Biosciences,

University of Algarve, Faro,

Portugal

Jaime Ramos, MD

Diana Carvalho, MD

Gastroenterology

Department, Centro

Hospitalar de Lisboa,

Lisboa, Portugal 
Ana Rita Gonçalves, MD

Gastroenterology

Department, Centro

Hospitalar Lisboa Norte,

Lisboa, Portugal

Paula Ministro, MD

Paula Sousa, MD

Gastroenterology

Department, Hospital de S.

Teotónio, Viseu, Portugal

Isadora Rosa, MD, PhD

João Pereira da Silva, MD

Gastroenterology

Department, Instituto

Português de Oncologia de

Lisboa, Lisboa, Portugal

Ana Isabel Vieira, MD

Tânia Meira, MD

Gastroenterology

Department, Hospital

Garcia de Orta, Almada,

Portugal

Cláudia Camila Dias, MSc

Department of

Pharmacology and

Therapeutics, Faculty of

Medicine, University of

Porto, Porto, Portugal

Yehuda Chowers, MD, PhD

Gastroenterology

Department, Rambam

Health Care Campus and

Bruce Rappaport School of

Medicine, Technion Israel

Institute of Technology.

Israel

Shomron Ben-Horin, MD, PhD

IBD Service, Department

of Gastroenterology,

Sheba Medical Center

and Sackler School

of Medicine, Tel-Aviv

University, Israel

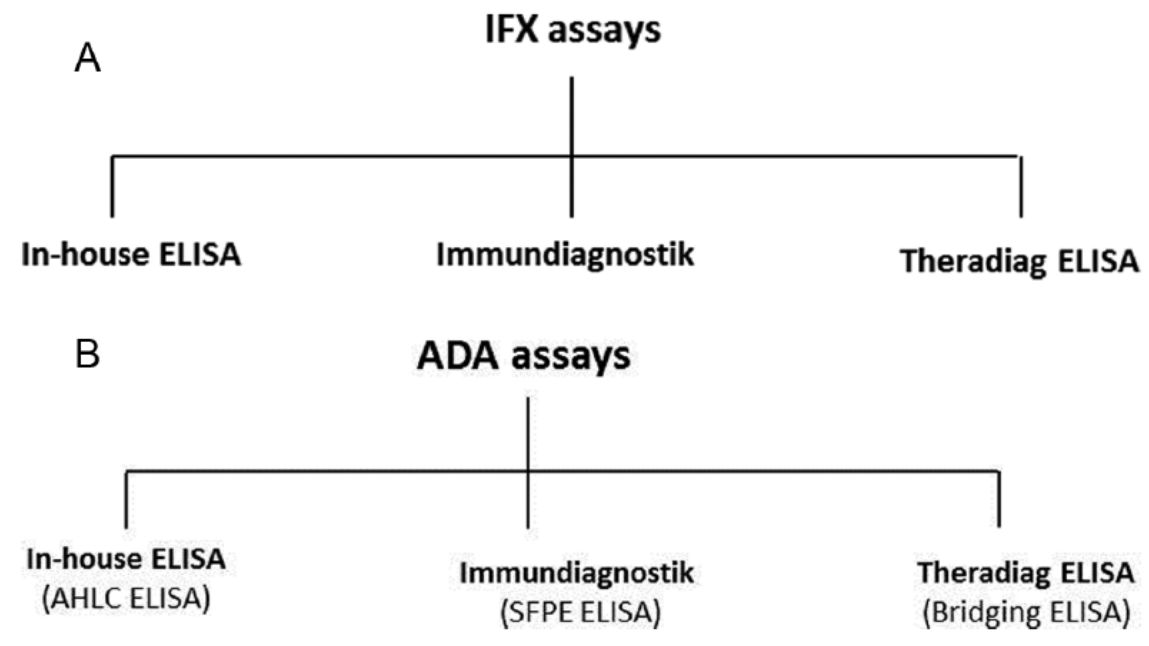

Figure 1. (A) Infliximab assays. (B) Anti-infliximab antibodies assays.

Hanauer, 2011; Steenholdt et al. 2013]. When managing loss of response, clinicians may empirically intensify treatment with the existing drug (increase dosage and/or increase frequency), switch to another TNF- $\alpha$ antagonist or switch to a totally different class of drug. This empirical approach has disadvantages: risk of irreversible tissue damage while the physician searches for an effective new drug, and significant economic consequences of unsuccessful trial and errors [Bendtzen and Svenson, 2011; Steenholdt et al. 2014a]. A more astute strategy is probably to use therapeutic drug monitoring (TDM), which enables clinicians to identify patients in whom a medication or change in medication is likely to be effective [Roblin et al. 2014; Steenholdt et al. 2014b; Yanai et al. 2015]. Indeed, a rational evidencebased and tailored therapy according to individual needs may reduce delays in effective treatment [Bendtzen, 2013; Steenholdt et al. 2014b].

Awareness of the value of TDM has led to the development of different techniques for assessing levels of infliximab and anti-infliximab antibodies (ADA) in patients, but these different methodologies have distinctive limitations and may yield different results. This potential bias may have a significant impact on TDM results and interpretation. There is still little information allowing us to compare different assays, in particular in relation to ADAs detection, which is likely to be subject to interference by detectable levels of IFX [Casteele et al. 2012; Kopylov et al. 2012; Steenholdt et al. 2013].

In order to incorporate therapeutic drug monitoring into clinical practice it is pertinent to recognize the potential for assay heterogeneity and accuracy. Therefore, the objective of this study was to evaluate and compare three different methodologies used to detect IFX and ADA and to clarify the importance of detectable IFX levels when measuring ADA levels namely on the accuracy of ADA assays.

\section{Methods}

\section{Patients and sera}

Trough blood samples were collected from 79 IFX treated ulcerative colitis (UC) patients. Blood samples were centrifuged, and the serum collected and stored at $-80^{\circ} \mathrm{C}$. This was a multicenter, open-label, single-arm trial. Study participants were recruited from ten IBD centers in Portugal. The trial was conducted in accordance with the Declaration of Helsinki and Ethical Principles of Good Clinical Practice and was approved by the local Ethics Committees. All participants gave their written informed consent.

\section{Evaluation of IFX levels}

IFX levels were evaluated using a sandwich enzyme-linked immunosorbent assay (ELISA) from three different sources (Figure 1A): one inhouse ELISA and two commercial ELISA kits. The upper limit of the measurement for the three assays was calculated as the highest concentration of the standard curve $\times$ sample dilution factor used.

IFX levels were evaluated using the in-house ELISA as previously described by Baert and 
colleagues with some modifications [Baert et al. 2003; Ben-Horin et al. 2011]. Briefly, $100 \mathrm{ml}$ of 1:100 diluted serum was added to a plate precoated with $750 \mathrm{ng} / \mathrm{ml}$ TNF $\alpha$ (Peprotech, Rocky Hill, NJ, USA) and incubated for $60 \mathrm{~min}$. Following washing, horseradish peroxidase (HRP) labelled goat anti-human Fc fragment antibody (MP Biomedicals, Solon, OH, USA) at a concentration of $0.62 \mu \mathrm{g} / \mathrm{ml}$ was added for 60 min. After washing, a 3-min reaction was performed with tetramethylbenzidine (TMB) substrate and stopped with $\mathrm{H}_{2} \mathrm{SO}_{4}, 2 \mathrm{M}$. The results were read at $450 / 540 \mathrm{~nm}$ using a Power Wave 340 (Biotec Instruments). The infliximab concentration was quantified using a standard curve constructed using exogenous infliximab (Schering Plough, NJ, USA). The lower limit of quantification was $0.1 \mu \mathrm{g} / \mathrm{ml}$.

IFX levels were also evaluated in parallel using the commercial TNF $\alpha$-Blocker ELISA (Immundiagnostik AG, Germany) and LisaTracker Premium Infliximab ELISA (Theradiag, France) kits according to the instructions provided by the manufacturer. The lower limit of quantification was 0.5 and $0.1 \mu \mathrm{g} / \mathrm{ml}$, for Immundiagnostik and Theradiag, respectively.

\section{Evaluation of ADA levels}

Antibodies to infliximab were evaluated using three distinct methodologies (Figure 1B), one inhouse assay [anti-human lambda chain assay (AHLC)], and two commercially available kits [a semi-quantitative assay, $\mathrm{TNF} \alpha-$ Blocker ADA (Immundiagnostik AG, Germany); and a quantitative assay, Lisa-Tracker Premium Infliximab ELISA (Theradiag, France)]. The upper limit of the measurement for the three assays was calculated as the highest concentration of the standard curve $\times$ sample dilution factor used.

In-house AHLC. ADA levels were determined in all samples using an in-house ELISA as previously described by Ben-Horin and colleagues [Ben-Horin et al. 2011]. The AHLC is a sandwich ELISA that uses anti-human lambda chain conjugate antibody in the detection step, taking advantage of the exclusively kappa chain composition of IFX [Kopylov et al. 2012]. Briefly, IFX was added to a plate precoated with TNF $\alpha$ (Peprotech, Rocky Hill, NJ, USA). After Diluted serum was added and incubated for $60 \mathrm{~min}$ at room temperature. Goat anti-human lambda chain HRP-labeled antibody (Serotec, Oxford, UK) was added and incubated for $60 \mathrm{~min}$, at room temperature. After a 6-min reaction with TMB the reaction was stopped with $\mathrm{H}_{2} \mathrm{SO}_{4}$. Absorbances were read at $450 / 540 \mathrm{~nm}$ and the results are expressed as $\mu \mathrm{g} / \mathrm{ml}$-equivalent $(\mu \mathrm{g} / \mathrm{ml}-\mathrm{e})$ after normalization against results obtained using a standard curve of goat anti-human $\mathrm{F}(\mathrm{ab}$ ') 2 fragment antibody (MP Biomedicals). For the purpose of brevity, the results are thereafter expressed as $\mu \mathrm{g} / \mathrm{ml}$, rather than $\mu \mathrm{g} / \mathrm{ml}$-e. The lower limit of quantification was $1.2 \mu \mathrm{g} / \mathrm{ml}$.

Immundiagnostik semi-fluid phase enzyme immunoassay. ADA levels were determined in a semifluid phase enzyme immunoassay (SFPE) using a commercial kit (TNF $\alpha$-Blocker ADA) purchased from Immundiagnostik (Germany) according to the instructions provided by the manufacturer. The SFPE uses an initial acid buffer treatment to dissociate the IFX-ADA immune complexes and two IFX conjugates with different conjugates. Acidified samples are incubated with IFX-biotin conjugate which immobilizes ADAs on the plate, and IFX-peroxidase conjugate is used for detection [Imaeda et al. 2012].

Theradiag bridging ELISA. ADA levels were determined in a bridging ELISA (BE) performed using a commercial kit (Lisa-Tracker Premium Infliximab ELISA) purchased from Theradiag (France) according to the instructions provided by the manufacturer. The BE uses a double-antigen bridge: ADAs create a bridge between IFX immobilized on the plate and IFX enzyme-linked conjugate. A total of 4 out of 79 samples determined with Theradiag were higher than the upper limit of the kit: in these cases the upper limit was considered as the result. The lower limit of quantification was $10 \mathrm{ng} / \mathrm{ml}$.

\section{Exogenous IFX in ADA-positive sera samples}

Exogenous IFX (Schering Plough, NJ, USA) was used to spike ADA-positive sera samples that contained undetectable levels of IFX.

Evaluation of exogenous IFX incubation time. The incubation time of exogenous IFX in sera was evaluated. Sera samples with ADAs and undetectable levels of IFX were incubated with several concentrations of IFX $(5,10,15,30,100$ and $300 \mu \mathrm{g} / \mathrm{ml})$ for different lengths of time $(0$, $0.5,3,6,12$ and $24 \mathrm{~h}$ ). Levels of ADAs were then determined using the AHLC assay as described above. 
Evaluation of stratified ADA levels (four groups) with exogenous IFX spiking using AHLC methodology. Four groups with undetectable IFX $(<0.1$ $\mu \mathrm{g} / \mathrm{ml}$ ) were stratified according to ADA-positive concentration as previously measured by AHLC assay: group A (ADAs within $1.7-3 \mu \mathrm{g} / \mathrm{ml}$ ); group B (ADAs within 3-10 $\mu \mathrm{g} / \mathrm{ml}$ ); group C (ADAs within $10-25 \mu \mathrm{g} / \mathrm{ml}$ ); group D (ADAs $>25 \mu \mathrm{g} /$ $\mathrm{ml})$. Sera were preincubated with several concentrations of exogenous $\operatorname{IFX}(5,10,30,100$ and 300 $\mu \mathrm{g} / \mathrm{ml}$ ) for $30 \mathrm{~min}$, at room temperature. Levels of ADAs were then determined using the in-house AHLC ELISA as described above.

Evaluation of ADA levels with exogenous IFX spiking in two groups of sera samples using three different methodologies. Two groups of ADApositive sera with undetectable IFX $(<0.1 \mu \mathrm{g} / \mathrm{ml})$ were selected from sera previously measured by AHLC assay: high levels of ADAs $(>25 \mu \mathrm{g} / \mathrm{ml})$ and intermediate levels of ADAs $(>3 \mu \mathrm{g} / \mathrm{ml}$ and $<10 \mu \mathrm{g} / \mathrm{ml})$. Sera were preincubated with several concentrations of exogenous IFX $(5,10,15,30$, 100 and $300 \mu \mathrm{g} / \mathrm{ml}$ ) for $30 \mathrm{~min}$, at room temperature. Levels of ADAs were then determined using the three different methodologies: in-house AHLC, Immundiagnostik SFPE and Theradiag $\mathrm{BE}$ as described above.

\section{Measurement of ADA IgG4 in the sera}

Sera samples containing ADAs were evaluated for ADA IgG4. ADA IgG4 levels were determined using an ELISA developed and described by Bendtzen and colleagues and adapted for IgG4 detection [Bendtzen and Svenson, 2011; Steenholdt, 2013]. Briefly, diluted serum was added and incubated for $60 \mathrm{~min}$ at room temperature to a plate precoated with anti-IgG4 antibody (Serotec, Oxford, UK). Plates were then washed and HRP-labeled infliximab was added for 60 min, at room temperature. A 5-min reaction with TMB substrate was performed and stopped with 2 $\mathrm{M} \mathrm{H}_{2} \mathrm{SO}_{4}$. Absorbances were read at $450 / 540 \mathrm{~nm}$ and the results were expressed as $\mu \mathrm{g} / \mathrm{ml}$-e after normalization against results obtained using a standard curve of goat anti-human $\mathrm{F}(\mathrm{ab}$ ')2 fragment antibody (MP Biomedicals).

\section{Statistical analysis}

The intraclass correlation coefficient (ICC) was used to determine the quantitative agreement between IFX levels evaluated by the three assays. ICC within 0.4 and 0.75 was considered moderate, lower than 0.4 poor and higher than 0.75 excellent. Agreement between assays was also assessed using Bland-Altman analysis, in which the mean differences and limits of agreement are descriptive. The KAPPA coefficients of $0-0.20$ were considered to indicate slight, 0.21-0.40 fair, $0.41-0.60$ moderate, $0.61-0.80$ substantial and 0.81-1 almost perfect agreement [Landis and Koch, 1977]. The mean difference (bias) and its 95\% confidence interval (CI) were computed. Limits of agreement (LOAs) were defined as mean difference \pm 2 standard deviations of difference (LOA = bias \pm SDD). Ninetyfive per cent of differences are expected to lie between LOAs.

The quantitative agreement between assays for ADA could not be assessed because data were reported using different and arbitrary units $(\mathrm{AU} / \mathrm{ml})$.

Kappa coefficient and percentage agreement were therefore used to determine the qualitative agreement between IFX levels, ADAs and status (IFX+/ADAs-; IFX+/ADAs +; IFX-/ADAs-; IFX-/ADAs-). Correlations between assays were determined only for IFX levels using linear correlation analysis expressed as Pearson's correlation coefficient (Pearson's $r$ ).

\section{Results}

IFX levels

A total of 79 sera samples were evaluated for IFX levels using three types of ELISA. Samples were collected from multicentric cohort of UC patients, composed of $44 \%$ men and with a median [interquartile range (IQR)] age of 35 (23-48) years. All patients were in the maintenance phase (after 14 weeks). A total of $35 \%$ of the patients were in IFX monotherapy and the remain cohort in concomitant therapy [38\% azathioprine (AZA); $12 \%$ 5-aminosalicylic acid (5-ASA); 7\% AZA + 5ASA; $1 \%$ methotrexate; $1 \%$ corticosteroids; $2 \%$ AZA + 5-ASA + corticosteroids; $1 \%$ AZA + corticosteroids + antibiotics].

Quantitative agreement was calculated using the ICC and mean differences (Table 1). Comparisons showed that ICC varied from a moderate agreement of $0.694 \quad(0.618-0.805)$ between Immundiagnostik and Theradiag up to an excellent agreement of $0.957(0.933-0.972)$ between the in-house ELISA and Immundiagnostik kit. 
Table 1. Intraclass correlation (ICC) and mean differences between different assays.

\begin{tabular}{lccccc} 
& ICC & $95 \% \mathrm{Cl}$ & \multicolumn{2}{c}{ Differences } \\
\cline { 5 - 6 } & & & & Mean & $95 \% \mathrm{Cl}$ \\
\hline IFX & & & & \\
In-house ELISA/ Theradiag ELISA & 0.762 & $0.627-0.848$ & 3.99 & $2.63-5.36$ \\
In-house ELISA/ Immundiagnostik ELISA & 0.957 & $0.933-0.972$ & -0.43 & -1.31 to 0.44 \\
Immundiagnostik ELISA / Theradiag ELISA & 0.694 & $0.618-0.805$ & 4.43 & $2.76-6.10$ \\
\hline Cl, confidence interval; ELISA, enzyme-linked immunosorbent assay; IFX, infliximab. & & \\
\hline
\end{tabular}

Mean differences (bias) confirmed the ICC evaluation. Moreover, a Bland and Altman plot analysis (graphics not shown) indicate that the significant bias between in-house and Theradiag is a result of dispersion of values along all of infliximab concentration, even for minor concentrations. Regarding in-house and Immundiagnostik, bias is more significant for concentrations higher than $15 \mu \mathrm{g} / \mathrm{ml}$.

The Pearson correlation between different assays was also calculated: $0.84(\mathrm{p}<0.001)$ for in-house versus Theradiag; $0.79(p<0.001)$ for Theradiag versus Immundiagnostik and $0.92(\mathrm{p}<0.001)$ for in-house versus Immundiagnostik.

In order to quantify the qualitative agreement of the different methods, two different cutoffs were applied to the measured concentrations: one used the limit of detection determined by the manufacturers for each assay as the cutoff, conveying an analytical perspective; and the other used clinically relevant cutoffs, as defined in the literature [Kopylov et al. 2012; Ungar et al. 2015].

Regarding the analytical approach, IFX was considered positive when above $0.1 \mu \mathrm{g} / \mathrm{ml}$ using the in-house and Theradiag methods. For the Immundiagnostik kit, positivity was considered for IFX concentrations above $0.5 \mu \mathrm{g} / \mathrm{ml}$. The in-house ELISA technique detected trough levels in 61 of 79 samples, a detection rate similar to that verified using the Immundiagnostik method (78\%). Using Theradiag the IFX trough levels were detected in fewer sera $(71 \%)$. The accuracy and KAPPA coefficients for these methods using the analytical cutoff are depicted in Table 2(A). In-house and Theradiag ELISA showed a moderate agreement (0.509), whereas the in-house/Immundiagnostik and Immundiagnostik/Theradiag had a substantial agreement (0.69 and 0.726, respectively). Moreover, a good accuracy was found among the three assays (81-88\%).
Considering the clinical approach, IFX was defined as positive for concentrations above $1 \mu \mathrm{g} / \mathrm{ml}$. The cutoff was settled taking in consideration cutoffs reported previously in the literature [Kopylov et al. 2012; Ungar et al. 2015].

The in-house ELISA detected positive IFX trough levels in 48 of the 79 samples $(61 \%)$, while the Immundiagnostik kit did so in 45 of the 79 samples (57\%) and the Theradiag kit did so in 49 of the 79 samples (62\%). The data regarding IFX trough levels obtained using the different assays is shown in Table 2(B).

The accuracy and KAPPA coefficient between the three different assays were calculated (Table 2B). All assays showed excellent agreement regarding IFX levels, with the KAPPA coefficient ranging from $0.835(0.709-0.960)$ between Immundiagnostik and Theradiag results, to 0.922 (0.836-1.000) between the in-house assay and Immundiagnostik results. A high level of accuracy was found between the three assays, with the inhouse and Immundiagnostik assays showing the highest accuracy (96\%).

\section{ADA levels}

The ICC and mean difference for ADAs could not be evaluated because the different assays used different units of measurement $(\mu \mathrm{g} / \mathrm{ml}$ for in-house assay and Theradiag and $\mathrm{AU} / \mathrm{ml}$ for Immundiagnostik).

From an analytical point of view, ADAs positivity was defined as levels above $1.2 \mu \mathrm{g} / \mathrm{ml}$ for in-house method, $0.01 \mu \mathrm{g} / \mathrm{ml}$ for the Theradiag kit and 10 $\mathrm{AU} / \mathrm{ml}$ for Immundiagnostik kit. All techniques have identified the same number of ADAspositive samples (46\%). Accuracy and KAPPA coefficient were calculated and are depicted in Table 3(A): a good accuracy was found for the 
Table 2. Agreement between different assays regarding levels of IFX: (A) analytical approach and (B) clinical approach.

\begin{tabular}{|c|c|c|}
\hline & \multicolumn{2}{|c|}{ Agreement } \\
\hline & Accuracy & $\begin{array}{l}\text { KAPPA } \\
{[95 \% \mathrm{Cl}]}\end{array}$ \\
\hline \multicolumn{3}{|c|}{$\begin{array}{l}\text { (A) IFX } \\
\text { (>0.1 } \mu \mathrm{g} / \mathrm{ml} \text { in-house and Theradiag; } 0.5 \mu \mathrm{g} / \mathrm{ml} \\
\text { Immundiagnostik) }\end{array}$} \\
\hline $\begin{array}{l}\text { In-house ELISA/ } \\
\text { Theradiag ELISA }\end{array}$ & $81 \%$ & $\begin{array}{l}0.509 \\
{[0.295-0.722]}\end{array}$ \\
\hline $\begin{array}{l}\text { In-house ELISA/ } \\
\text { Immundiagnostik } \\
\text { ELISA }\end{array}$ & $87 \%$ & $\begin{array}{l}0.697 \\
{[0.526-0.868]}\end{array}$ \\
\hline $\begin{array}{l}\text { Immundiagnostik } \\
\text { ELISA / Theradiag } \\
\text { ELISA }\end{array}$ & $88 \%$ & $\begin{array}{l}0.726 \\
{[0.559-0.893]}\end{array}$ \\
\hline \multicolumn{3}{|l|}{$\begin{array}{l}\text { (B) IFX } \\
(>1 \mu \mathrm{g} / \mathrm{ml})\end{array}$} \\
\hline $\begin{array}{l}\text { In-house ELISA/ } \\
\text { Theradiag ELISA }\end{array}$ & $92 \%$ & $\begin{array}{l}0.840 \\
{[0.716-0.963]}\end{array}$ \\
\hline $\begin{array}{l}\text { In-house ELISA/ } \\
\text { Immundiagnostik } \\
\text { ELISA }\end{array}$ & $96 \%$ & $\begin{array}{l}0.922 \\
{[0.836-1.000]}\end{array}$ \\
\hline $\begin{array}{l}\text { Immundiagnostik } \\
\text { ELISA / Theradiag } \\
\text { ELISA }\end{array}$ & $92 \%$ & $\begin{array}{l}0.835 \\
{[0.709-0.960]}\end{array}$ \\
\hline
\end{tabular}

three assays (82-85\%), whereas KAPPA coefficient shown a moderate agreement.

A clinical approach to the ADAs positivity is shown in Table 3(B). Samples were considered ADA-positive when levels exceeded $1.7 \mu \mathrm{g} / \mathrm{ml}$ for the in-house (AHLC) as applied by Kopylov and colleagues [Kopylov et al. 2012]. For Theradiag the same cutoff was applied. For the Immundiagnostik (SFPE) assay ADA-positive were considered when $>10$ AU (cutoff defined by the manufacturer for positivity). The in-house and Immundiagnostik assays detected ADAs in 34 out of 79 samples (43\%), while Theradiag detected ADAs in 24 out of 79 samples (30\%). Although the in-house and Immundiagnostik assays detected the same number of samples with ADAs not all samples matched. In fact, ADAs were confirmed by both the in-house and Immundiagnostik assay in 28 out of the 34 samples (82\%). Regarding the comparative performance of Theradiag with the in-house and Immundiagnostik assays, of the 24 samples with ADAs identified by Theradiag, $21(87.5 \%)$ were also positive in both the in-house
Table 3. Agreement between different assays regarding levels of ADAs: (A) analytical approach and (B) clinical approach.

\begin{tabular}{|c|c|c|}
\hline & \multicolumn{2}{|c|}{ Agreement } \\
\hline & Accuracy & $\begin{array}{l}\text { KAPPA } \\
{[95 \% \mathrm{CI}]}\end{array}$ \\
\hline \multicolumn{3}{|c|}{$\begin{array}{l}\text { (A) ADAs } \\
\text { ( }>1.2 \mu \mathrm{g} / \mathrm{ml} \text { for in-house and }>0.01 \mu \mathrm{g} / \mathrm{ml} \\
\text { Theradiag; }>10 \text { AU for Immundiagnostik) }\end{array}$} \\
\hline In-house/ Theradiag & $85 \%$ & $\begin{array}{l}0.695 \\
{[0.539-0.851]}\end{array}$ \\
\hline $\begin{array}{l}\text { In-house/ } \\
\text { Immundiagnostik }\end{array}$ & $82 \%$ & $\begin{array}{l}0.643 \\
{[0.472-0.814]}\end{array}$ \\
\hline $\begin{array}{l}\text { Theradiag / } \\
\text { Immundiagnostik }\end{array}$ & $82 \%$ & $\begin{array}{l}0.635 \\
{[0.463-0.807]}\end{array}$ \\
\hline \multicolumn{3}{|c|}{$\begin{array}{l}\text { (B) ADAs } \\
\text { ( }>1.7 \mu \mathrm{g} / \mathrm{ml} \text { for in-house and Theradiag; }>10 \mathrm{AU} / \\
\mathrm{ml} \text { for Immundiagnostik) }\end{array}$} \\
\hline In-house/ Theradiag & $81 \%$ & $\begin{array}{l}0.602 \\
{[0.435-0.769]}\end{array}$ \\
\hline $\begin{array}{l}\text { In-house/ } \\
\text { Immundiagnostik }\end{array}$ & $85 \%$ & $\begin{array}{l}0.692 \\
{[0.531-0.852]}\end{array}$ \\
\hline $\begin{array}{l}\text { Theradiag / } \\
\text { Immundiagnostik }\end{array}$ & $83 \%$ & $\begin{array}{l}0.653 \\
{[0.492-0.814]}\end{array}$ \\
\hline \multicolumn{3}{|c|}{$\begin{array}{l}\text { AU, arbitrary units; } \mathrm{Cl} \text {, confidence interval; ELISA, } \\
\text { enzyme-linked immunosorbent assay; IFX, infliximab. }\end{array}$} \\
\hline
\end{tabular}

and Immundiagnostik assays. Nevertheless, the in-house and Immundiagnostik assays considered positive 13 and 12 samples, respectively, that were negative with Theradiag.

Moderate agreement was found between the inhouse and Theradiag assays, with a KAPPA coefficient of $0.602(0.435-0.769)$ while the in-house and Immundiagnostik assays showed good agreement with a KAPPA coefficient of $0.692(0.531-$ 0.852). Accuracy ranged from $81 \%$ to $85 \%$ among the different pairs of assays (Table 3B).

\section{IFX and ADA status}

Figure 2 depicts the levels of IFX and ADAs evaluated by all assays. The vertical dotted line separates samples positive for IFX from samples negative for IFX. The horizontal dotted line separates samples positive for ADAs from samples negative for ADAs. Both analytical and clinical perspectives are represented in Figure 2. From the analytical point of view, $71-77 \%$ of total samples are included in IFX + group, and $45 \%$ in anti-IFX + . On the other hand, from a clinical perspective all the three assays identified $25 \%$ of samples positive for ADAs and IFX-negative. 


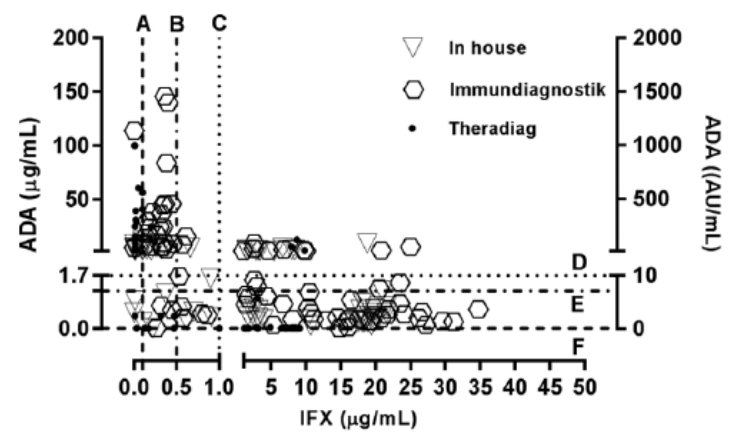

Figure 2. Levels of infliximab (IFX) and anti-infliximab antibodies (ADAs) determined by all methodologies. Dotted lines represent cutoffs for analytical approach (A, B, D, E and F) and clinical approach (C and D). Cutoffs for IFX levels: (A) $0.1 \mu \mathrm{g} / \mathrm{ml}$ lin-house and Theradiag); (B) $0.5 \mu \mathrm{g} / \mathrm{ml}$ (Immundiagnostik); (C) $1 \mu \mathrm{g} / \mathrm{ml}$ lall assays).

Cutoffs for ADAs levels: (D) $1.7 \mu \mathrm{g} / \mathrm{ml}$ lin-house and Theradiag) and $10 \mathrm{AU} / \mathrm{ml}$ (Immundiagnostik); (E) $1.2 \mu \mathrm{g} / \mathrm{ml}$ (in-house); (F) $0.01 \mu \mathrm{g} / \mathrm{ml}$ (Theradiag).

However, the group of samples that had a doublepositive status for both IFX and ADAs were identified almost exclusively by the in-house and Immundiagnostik assays. Theradiag detected only three samples that were positive for ADAs in the presence of the drug. However, these three samples were considered IFX-negative by the other two assays.

Thereafter, we focused on the double status of IFX and ADAs. As the IFX/ADAs group definition depends directly on the cutoffs applied, the two different approaches (analytical and clinical) were taken into consideration. Tables 4 and 5 show the agreement between assays for different combinations of IFX/ADA status from an analytical and clinical perspective, respectively.

IFX+/ADAs-. The analytical approach has shown that $50 \%$ of samples had an IFX+/ADAs-status (Table 4). Agreement between assays was considered good (85\%).

The clinical perspective exhibited a strong agreement ranging between 75.6 and $100 \%$ (Table 5). The poorest agreement between assays was observed when using Theradiag as the reference assay and Immundiagnostik as the confirmatory assay $(75.6 \%)$.

IFX+/ADAs+. The double-positive samples obtained using the cutoffs given by the analytical perspective is shown in Table 4 . The agreement was low $(31.3-50 \%)$. The lowest agreement rate occurred for Theradiag and Immundiagnostik (considering Theradiag as the standard assay).

In contrast, for the double-positive status (IFX+/ ADAs + ) defined using the clinical approach, there was a significant discrepancy between Theradiag and the in-house and Immundiagnostik assays. The in-house assay detected a total of 11 double-positive sera and Immundiagnostik a total of $10 \mathrm{IFX}+/$ ADAs + . Theradiag was able to detect three double-positive samples but neither were in agreement with the other assays. In fact, in those three samples, both the in-house and Immundiagnostik assay detected ADAs whereas IFX was considered undetectable.

IFX-/ADAs-. Using the analytical perspective (Table 4) only two or three double-negative samples were detected. Furthermore, Theradiag and the other two assays never agreed. The in-house and Immundiagnostik kit agreed in one out of three samples.

The detection of samples with double-negative status (IFX-/ADAs-) by clinical approach showed similar levels of agreement between pairs of assays (Table 5). When considering the in-house and Immundiagnostik assay there was $62.5 \%$ agreement, but when considering Theradiag as the reference assay, there was a lower level of agreement between methodologies (50-55.6\%).

IFX-/ADAs+. From an analytical perspective, Immundiagnostik and Theradiag had a good agreement (75-90\%) concerning IFX-/ADAs+. A very good agreement was also obtained for this status between the in-house and Immundiagnostik assays when considering in-house the standard test.

From the clinical point of view, IFX-/ADAs + status showed good agreement (more than 84\%) between the in-house and Immundiagnostik assays. The in-house and Theradiag assays showed a lower level of agreement, although it was still considered good at $90.5 \%$ and $79.2 \%$, respectively.

\section{Exogenous IFX in ADA-positive samples}

To evaluate the effect of IFX on in-house, Immundiagnostik and Theradiag assessment of ADAs in sera, an experiment was designed that involved spiking with exogenous IFX. The influence of exogenous IFX incubation time was assessed previously and no differences were found 
Table 4. Agreement between the three assays for all combinations of IFX/ADAs status (analytical approach).

\begin{tabular}{|c|c|c|c|c|c|}
\hline & & & & \multicolumn{2}{|c|}{ Agreement } \\
\hline & & & & Accuracy & $\begin{array}{l}\text { KAPPA } \\
{[95 \% \mathrm{CI}]}\end{array}$ \\
\hline \multicolumn{2}{|c|}{ In-house assay versus Theradiag assayla) } & \multicolumn{2}{|c|}{$\begin{array}{l}\text { Theradiag assay versus In-house } \\
\text { assay(b) }\end{array}$} & \multirow{3}{*}{$68 \%$} & \multirow{3}{*}{$\begin{array}{l}0.502 \\
{[0.355-0.649]}\end{array}$} \\
\hline $\begin{array}{l}\text { IFX + ADA- } \\
85 \%(n=40)\end{array}$ & $\begin{array}{l}\text { IFX }+ \text { ADA + } \\
38.1 \%(n=21)\end{array}$ & $\begin{array}{l}\text { IFX }+ \text { ADA - } \\
85 \%(n=40)\end{array}$ & $\begin{array}{l}\text { IFX + ANTI + } \\
50 \%(n=16)\end{array}$ & & \\
\hline $\begin{array}{l}\text { IFX - ADA - } \\
0 \%(n=2)\end{array}$ & $\begin{array}{l}\text { IFX - ADA + } \\
75.0 \%(n=16)\end{array}$ & $\begin{array}{l}\text { IFX - ADA - } \\
0 \%(n=2)\end{array}$ & $\begin{array}{l}\text { IFX - ADA+ } \\
57.1 \%(n=21)\end{array}$ & & \\
\hline \multicolumn{2}{|c|}{ In-house assay versus Immundiagnostik(c) } & \multicolumn{2}{|c|}{$\begin{array}{l}\text { Immundiagnostik assay versus In- } \\
\text { house assay(d) }\end{array}$} & \multirow{3}{*}{$72 \%$} & \multirow{3}{*}{$\begin{array}{l}0.566 \\
{[0.425-0.707}\end{array}$} \\
\hline $\begin{array}{l}\text { IFX + ADA - } \\
85.0 \%(n=40)\end{array}$ & $\begin{array}{l}\text { IFX }+ \text { ADA }+ \\
35.0 \%(n=20) \\
\end{array}$ & $\begin{array}{l}\text { IFX + ADA - } \\
85.0 \%(n=40)\end{array}$ & $\begin{array}{l}\mathrm{IFX}+\mathrm{ADA}+ \\
58.3 \%(n=12)\end{array}$ & & \\
\hline $\begin{array}{l}\text { IFX - ADA - } \\
33.3 \%(n=3)\end{array}$ & $\begin{array}{l}\text { IFX - ADA + } \\
93.8 \%(n=16)\end{array}$ & $\begin{array}{l}\text { IFX - ADA - } \\
33.3 \%(n=3)\end{array}$ & $\begin{array}{l}\text { IFX - ADA + } \\
62.5 \%(n=24)\end{array}$ & & \\
\hline \multicolumn{2}{|c|}{$\begin{array}{l}\text { Immundiagnostik assay versus Theradiag } \\
\text { assay(e) }\end{array}$} & \multicolumn{2}{|c|}{$\begin{array}{l}\text { Theradiag assay versus } \\
\text { Immundiagnostik(f) }\end{array}$} & \multirow{3}{*}{$77 \%$} & \multirow{3}{*}{$\begin{array}{l}0.562 \\
{[0.415-0.707}\end{array}$} \\
\hline $\begin{array}{l}\text { IFX + ADA - } \\
84.6 \%(n=39)\end{array}$ & $\begin{array}{l}\text { IFX }+ \text { ADA + } \\
41.7 \%(n=12)\end{array}$ & $\begin{array}{l}\text { IFX }+ \text { ADA - } \\
82.5 \%(n=40)\end{array}$ & $\begin{array}{l}\text { IFX }+ \text { ADA }+ \\
31.3 \%(n=16)\end{array}$ & & \\
\hline $\begin{array}{l}\text { IFX - ADA - } \\
0.0 \%(n=2)\end{array}$ & $\begin{array}{l}\text { IFX - ADA + } \\
75.0 \%(n=24)\end{array}$ & $\begin{array}{l}\text { IFX - ADA - } \\
0.0 \%(n=1)\end{array}$ & $\begin{array}{l}\text { IFX - ADA + } \\
90.0 \%(n=20)\end{array}$ & & \\
\hline \multicolumn{6}{|c|}{$\begin{array}{l}\text { (a) In-house assay was considered the reference assay and it was evaluated whether Theradiag confirmed the double status result. } \\
\text { (b) Theradiag assay was considered the reference assay and it was evaluated whether in-house confirmed the double status result. } \\
\text { (c)In-house assay was considered the reference assay and it was evaluated whether Immundiagnostik confirmed the double status result. } \\
\text { (d) Immundiagnostik assay was considered the reference assay and it was evaluated whether in-house confirmed the double status result. } \\
\text { (le) Immundiagnostik assay was considered the reference assay and it was evaluated whether Theradiag confirmed the double status result. } \\
\text { (If)Theradiag assay was considered the reference assay and it was evaluated whether Immundiagnostik confirmed the double status result. } \\
\text { Cl, confidence interval. }\end{array}$} \\
\hline
\end{tabular}

(data not shown). An incubation time of $30 \mathrm{~min}$ was selected for further experiments.

Evaluation of ADA levels with exogenous IFX spiking in four groups of sera samples. To evaluate whether different intrinsic concentrations of ADAs are important when assessing the influence of exogenous IFX, we used stratified concentrations of ADA levels in sera (four different groups as evaluated previously: $1.7-3,3-10,10-25$ and $>25 \mu \mathrm{g} / \mathrm{ml}$ ) and spiked them with exogenous IFX. The evaluation was performed using the inhouse assay only. The results are presented in Figure 3. In-house assay lost the capability to detect levels of antibodies in sera samples with ADA levels between 1.7 and $3 \mu \mathrm{g} / \mathrm{ml}$ at concentrations of IFX over $5 \mu \mathrm{g} / \mathrm{ml}$. The influence of exogenous IFX was also evident in the $3-10 \mu \mathrm{g} / \mathrm{ml}$ group, but loss of antibody detection capacity was only observed beyond $100 \mu \mathrm{g} / \mathrm{ml}$ IFX, which generally exceeds the therapeutic concentrations of infliximab in vivo even during induction phase [Adedokun et al. 2014]. A decreased ADA detection capacity was observed in the two upper groups (10-25 and $>25 \mu \mathrm{g} / \mathrm{ml}$ ) in a concentrationdependent manner, but in both groups the inhouse assay was able to detect antibodies even with $300 \mu \mathrm{g} / \mathrm{ml}$ of exogenous IFX. Nevertheless, a significant reduction of detection capacity of $75 \%$ and $61 \%$ was observed in the $10-25 \mu \mathrm{g} / \mathrm{ml}$ and $>25 \mu \mathrm{g} / \mathrm{ml}$ groups, respectively.

Evaluation of ADA levels with exogenous IFX spiking in two groups: high and intermediate levels of ADAs. Taking into account the above-mentioned results, we decided to explore the performance of 
Table 5. Agreement between the three assays for all combinations of IFX/ADAs status (clinical approach).

\begin{tabular}{|c|c|c|c|c|c|}
\hline & & & & \multicolumn{2}{|c|}{ Agreement } \\
\hline & & & & Accuracy & $\begin{array}{l}\text { KAPPA } \\
{[95 \% \mathrm{Cl}]}\end{array}$ \\
\hline \multicolumn{2}{|c|}{$\begin{array}{l}\text { In-house assay versus Theradiag } \\
\text { assay(a) }\end{array}$} & \multicolumn{4}{|c|}{ Theradiag assay versus In-house assay ${ }^{(b)}$} \\
\hline $\begin{array}{l}\text { IFX + ADA- } \\
100 \%(n=35)\end{array}$ & $\begin{array}{l}\text { IFX + ADA + } \\
0 \%(n=11)\end{array}$ & $\begin{array}{l}\text { IFX + ADA - } \\
77.8 \%(n=45)\end{array}$ & $\begin{array}{l}\mathrm{IFX}+\mathrm{ANTI}+ \\
0 \%(n=3)\end{array}$ & \multirow[t]{3}{*}{$76 \%$} & \multirow[t]{2}{*}{$\begin{array}{l}0.620 \\
{[0.489-0.751]}\end{array}$} \\
\hline $\begin{array}{l}\text { IFX - ADA - } \\
62.5 \%(n=8)\end{array}$ & $\begin{array}{l}\text { IFX - ADA + } \\
79.2 \%(n=24)\end{array}$ & $\begin{array}{l}\text { IFX - ADA - } \\
55.6 \%(n=9)\end{array}$ & $\begin{array}{l}\text { IFX - ADA }+ \\
90.5 \%(n=21)\end{array}$ & & \\
\hline \multicolumn{2}{|c|}{$\begin{array}{l}\text { In-house assay versus } \\
\text { Immundiagnostik(c) }\end{array}$} & \multicolumn{2}{|c|}{$\begin{array}{l}\text { Immundiagnostik assay versus In-house } \\
\text { assay(d) }\end{array}$} & & \multirow{3}{*}{$\begin{array}{l}0.716 \\
{[0.591-0.841]}\end{array}$} \\
\hline $\begin{array}{l}\text { IFX + ADA - } \\
83.8 \%(n=37)\end{array}$ & $\begin{array}{l}\text { IFX + ADA + } \\
54.5 \%(n=11)\end{array}$ & $\begin{array}{l}\text { IFX }+ \text { ADA - } \\
88.6 \%(n=35)\end{array}$ & $\begin{array}{l}\text { IFX }+ \text { ADA }+ \\
60 \%(n=10)\end{array}$ & \multirow[t]{3}{*}{$81 \%$} & \\
\hline $\begin{array}{l}\text { IFX - ADA - } \\
62.5 \%(n=8)\end{array}$ & $\begin{array}{l}\text { IFX - ADA + } \\
95.7 \%(n=23)\end{array}$ & $\begin{array}{l}\text { IFX - ADA - } \\
62.5 \%(n=8)\end{array}$ & $\begin{array}{l}\text { IFX - ADA + } \\
84.6 \%(n=26)\end{array}$ & & \\
\hline \multicolumn{2}{|c|}{$\begin{array}{l}\text { Immundiagnostik assay versus } \\
\text { Theradiag assayle) }\end{array}$} & \multicolumn{2}{|c|}{$\begin{array}{l}\text { Theradiag assay versus } \\
\text { Immundiagnostik }{ }^{(\mathrm{f})}\end{array}$} & & \multirow{3}{*}{$\begin{array}{l}0.625 \\
{[0.491-0.758]}\end{array}$} \\
\hline $\begin{array}{l}\text { IFX + ADA - } \\
100 \%(n=34)\end{array}$ & $\begin{array}{l}\mathrm{IFX}+\mathrm{ADA}+ \\
0 \%(n=10)\end{array}$ & $\begin{array}{l}\text { IFX + ADA - } \\
75.6 \%(n=45)\end{array}$ & $\begin{array}{l}\mathrm{IFX}+\mathrm{ADA}+ \\
0 \%(n=3)\end{array}$ & \multirow[t]{2}{*}{$76 \%$} & \\
\hline $\begin{array}{l}\text { IFX - ADA - } \\
66.7 \%(n=6)\end{array}$ & $\begin{array}{l}\text { IFX - ADA + } \\
76.9 \%(n=26)\end{array}$ & $\begin{array}{l}\text { IFX - ADA - } \\
50 \%(n=8)\end{array}$ & $\begin{array}{l}\text { IFX - ADA + } \\
100 \%(n=20)\end{array}$ & & \\
\hline \multicolumn{6}{|c|}{$\begin{array}{l}\text { (a)In-house assay was considered the reference assay and it was evaluated whether Theradiag confirmed the double status result. } \\
\text { (b) Theradiag assay was considered the reference assay and it was evaluated whether in-house confirmed the double status result. } \\
\text { (c)In-house assay was considered the reference assay and it was evaluated whether Immundiagnostik confirmed the double status result. } \\
\text { (d)Immundiagnostik assay was considered the reference assay and it was evaluated whether in-house confirmed the double status result. } \\
\text { (e)Immundiagnostik assay was considered the reference assay and it was evaluated whether Theradiag confirmed the double status result. } \\
\text { (f) Theradiag assay was considered the reference assay and it was evaluated whether Immundiagnostik confirmed the double status result. } \\
\text { Cl, confidence interval. }\end{array}$} \\
\hline
\end{tabular}

the three assays under the interference of exogenous IFX. The two most representative groups were used: samples with ADAs within 3-10 $\mu \mathrm{g} / \mathrm{ml}$ (intermediate) and those with $>25 \mu \mathrm{g} / \mathrm{ml}$ (high level). Figures 4 and 5 present the results of the groups spiked with exogenous IFX at different concentrations $(0,5,10,15,30,100$ and $300 \mu \mathrm{g} / \mathrm{ml})$. Table 6 shows the half maximal inhibitory concentrations $\left(\mathrm{IC}_{50}\right)$.

Figure 4 (high levels of ADAs) illustrates that exogenous IFX only interfered with ADA detection at concentrations higher than $100 \mu \mathrm{g} / \mathrm{ml}$. Spiking $100 \mu \mathrm{g} / \mathrm{ml}$ of exogenous IFX in sera samples with high levels of ADA resulted in a decline in ADA detection of $87 \%, 46 \%$ and $16 \%$ in the Theradiag, in-house and Immundiagnostik assays, respectively. Nevertheless, in-house showed a higher $\mathrm{IC}_{50}$ than Theradiag, at $143.6 \mu \mathrm{g} / \mathrm{ml}$ versus $74.9 \mu \mathrm{g} / \mathrm{ml}$, respectively, indicating that it was less affected than Theradiag by the presence of IFX. In the Immundiagnostik assay the influence of exogenous IFX showed a lower decline in ADA detection. In fact, $300 \mu \mathrm{g} / \mathrm{ml}$ decreased ADA detection by $17 \%$ (the $\mathrm{IC}_{50}$ was therefore impossible to determine), while in in-house and Theradiag assays, ADA detection decreased by $75 \%$ and $93 \%$, respectively. However, all methodologies were able to detect ADAs, in sera originally positive for high levels of ADAs, even with $300 \mu \mathrm{g} / \mathrm{ml}$ of exogenous IFX.

Figure 5 shows exogenous IFX interference in sera samples with intermediate levels of ADAs. The presence of exogenous IFX decreased ADA detection in Theradiag and in-house with the 


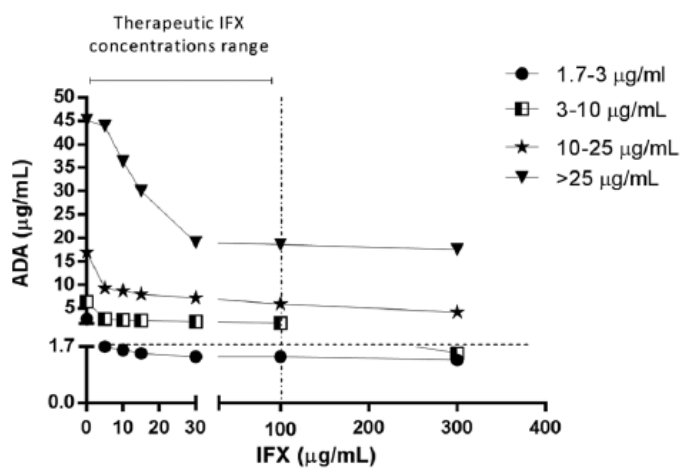

Figure 3. Stratified anti-infliximab antibodies (ADA) levels in the presence of exogenous infliximab (IFX), evaluated by in-house assay. Therapeutic IFX concentrations range was considered between 0 and $100 \mu \mathrm{g} / \mathrm{ml}$ [Adedokun et al. 2014]. lower concentration $(5 \mu \mathrm{g} / \mathrm{ml})$ of exogenous IFX. For Theradiag this decrease led to the inability to detect ADAs and consequently it was impossible to determine the $\mathrm{IC}_{50}$. In-house showed an IC $_{50}$ of $0.88 \mu \mathrm{g} / \mathrm{ml}$ while Immundiagnostik showed a higher value of $140.1 \mu \mathrm{g} / \mathrm{ml}$. At 300 $\mu \mathrm{g} / \mathrm{ml}$ the interference was stronger in Theradiag $(97 \%)$ while in in-house detection decreased by $74 \%$. In-house failed to detect ADAs at IFX concentrations of $300 \mu \mathrm{g} / \mathrm{ml}$, which are above the therapeutic levels achieved in vivo. Above $30 \mu \mathrm{g} / \mathrm{ml}$ IFX the Immundiagnostik assay was influenced by an additive concentration effect but was able to detect ADAs even at the higher concentration $(300 \mu \mathrm{g} / \mathrm{ml})$ of exogenous IFX (total decrease of $60 \%$ ).

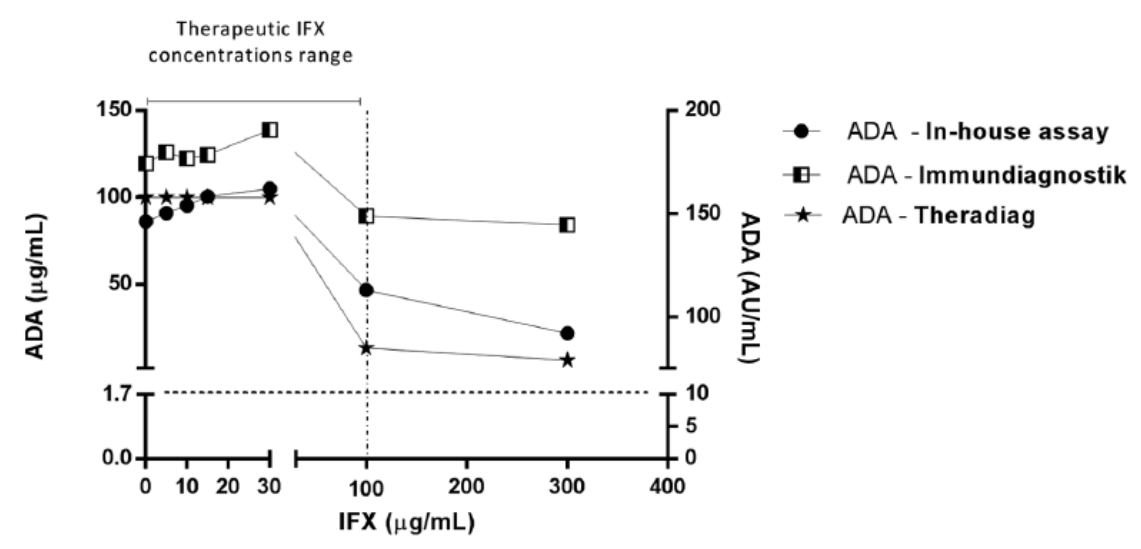

Figure 4. High anti-infliximab antibodies (ADAs) levels in the presence of exogenous infliximab (IFX) evaluated by in-house, Immundiagnostik and Theradiag assay. Therapeutic IFX concentrations range was considered between 0 and $100 \mu \mathrm{g} / \mathrm{ml}$ [Adedokun et al. 2014].

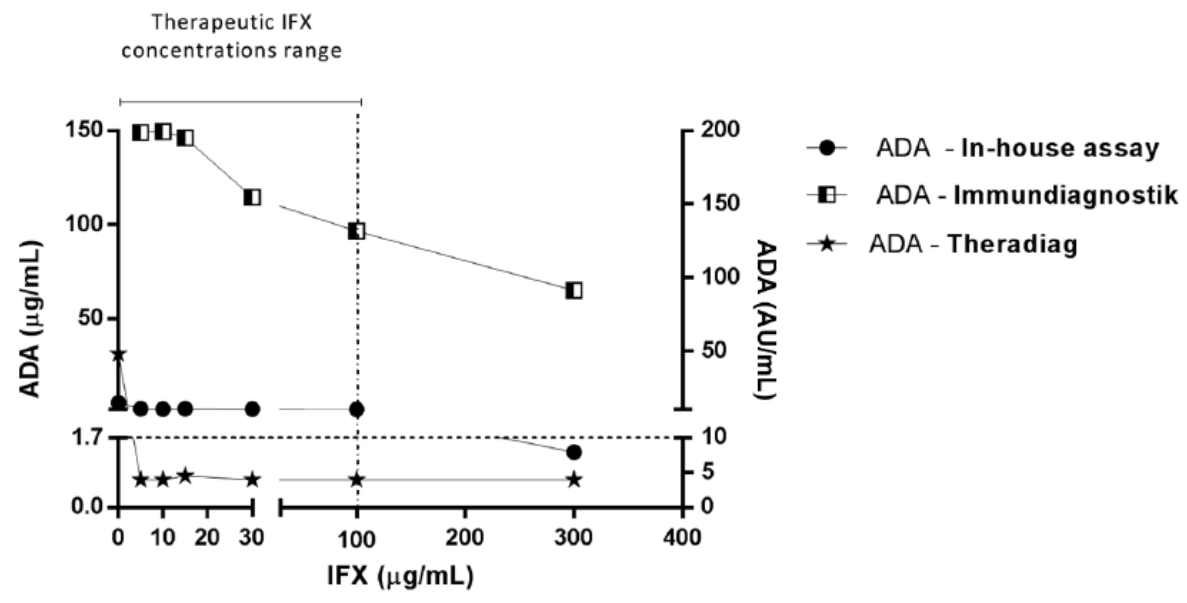

Figure 5. Intermediate anti-infliximab antibodies (ADAs) levels in the presence of exogenous infliximab (IFX) evaluated by in-house, Immundiagnostik and Theradiag assay. Therapeutic IFX concentrations range was considered between 0 and $100 \mu \mathrm{g} / \mathrm{ml}$ [Adedokun et al. 2014]. 
Table 6. Infliximab (IFX) inhibition effect on ADAs at intermediate and high levels in different assays.

\begin{tabular}{|c|c|c|}
\hline & \multicolumn{2}{|l|}{$\mathrm{IC}_{50}(\mu \mathrm{g} / \mathrm{ml})$} \\
\hline & $\begin{array}{l}\text { Intermediate levels } \\
3 \mu \mathrm{g} / \mathrm{ml}>\mathrm{ADA}<10 \mu \mathrm{g} / \mathrm{ml}\end{array}$ & $\begin{array}{l}\text { High levels } \\
\text { ADA }>25 \mu \mathrm{g} / \mathrm{ml}\end{array}$ \\
\hline In-house (AHLC) & 0.88 & 143.60 \\
\hline Immundiagnostik (SPFE) & 140.10 & NA \\
\hline Theradiag (BE) & NA & 74.89 \\
\hline \multicolumn{3}{|c|}{$\begin{array}{l}I_{50} \text {, half maximal inhibitory concentration; NA, IC } \mathrm{C}_{50} \text { value not determined because either } 50 \% \text { inhibition fell outside the } \\
\text { highest concentration or because inhibition was } 100 \% \text { above the lowest concentration of IFX; ADA, anti-infliximab anti- } \\
\text { bodies; AHLC, anti-human lambda chain; SPFE, semi-fluid phase enzyme; BE, bridging enzyme-linked immunosorbent } \\
\text { assay. }\end{array}$} \\
\hline
\end{tabular}

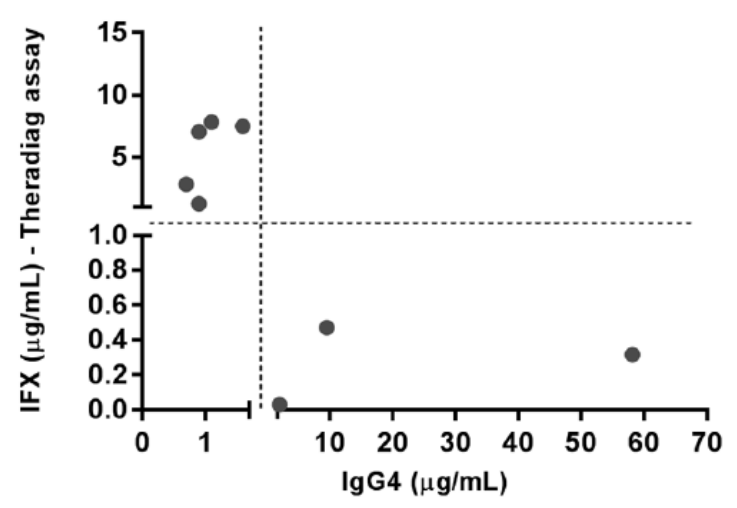

Figure 6. Levels of IFX and IgG4 in samples that were ADA-negative in Theradiag and ADA-positive in both the in-house and Immundiagnostik assays.

\section{$\lg G 4$ ADAs}

In order to evaluate the influence of IgG4 ADAs, samples positive for ADAs were tested for the presence of IgG4. IgG4 ADAs were found in $54.8 \%$ of the ADA-positive samples. Figure 6 shows the levels of IFX and IgG4 in samples that were ADA-negative with Theradiag but ADApositive for both the in-house and Immundiagnostik assays. Of the eight samples negative for antibodies with Theradiag, five presented positive levels of IFX and three presented IgG4 ADAs.

\section{Discussion}

Several methodologies are available for use in drug monitoring. However, different methodologies return different results. There is still little information comparing different assays, in particular for ADA detection, which is susceptible to interference in the presence of detectable levels of IFX.

The aim of this study was to evaluate and compare three different assays for detecting IFX and
ADAs and to clarify the importance of the presence of detectable levels of IFX on the accuracy of the ADA assays.

Cutoffs for a qualitative evaluation of the assays are difficult to establish, particularly for ADAs assays. In fact, ADAs results are expressed in different units by the different assays. In addition, Immundiagnostik defines a cutoff for positivity that is different from the limit of detection and not suggested by all commercial assays. The manufacturers' instruction for Theradiag do not contain any suggestion for a cutoff for ADAs positivity besides the limit of detection of $0.01 \mu \mathrm{g} / \mathrm{ml}$. Van Schouwenburg and colleagues have shown that BE assays (Theradiag methodology) performance is depend not only of the amount of antibody in the serum but also of the affinity of ADAs to the assay [Van Schouwenburg et al. 2016]. This indicates a possible source of intervariability of the assay, namely for values near the limit of detection. In fact, our results show that with Theradiag $70 \%$ of the values considered to be positive, with analytical approach, are between 0.01 and $0.04 \mu \mathrm{g} / \mathrm{ml}$. This might be a reflection of the intervariability of the assay, rather than a faithful quantification of the presence of antibodies. Taking this into consideration, we have decided to perform two different approaches in the qualitative analyses of the results: an analytical one, in which cutoffs were defined by the manufacturers' instructions; and a clinical one, in which the cutoffs were defined according to the literature.

From an analytical perspective, IFX assays showed a substantial agreement and a good accuracy, although the in-house and Theradiag methods had only a moderate agreement. On the other hand, upon applying a cutoff of $1 \mu \mathrm{g} / \mathrm{ml}$, the behavior of the three assays is very similar. 
This suggests that using the limit of detection as a cutoff may decrease the quality agreement between assays.

The behavior of the three assays in terms of IFX determination was very similar. In fact, an accuracy of over $92 \%$ for IFX was observed when analyzing the agreement between the three assays. An agreement of $100 \%$ (data not shown) was observed between the in-house and Immundiagnostik assays for IFX-negative samples, while the Theradiag assay identified four IFX-positive samples that the other two assays returned as negative. Casteele and colleagues also evaluated three IFX assays based on the sandwich ELISA principle and found good correlation between them [Casteele et al. 2012]. The authors used the same commercial kit as used here (Theradiag). In fact, Theradiag returned 11 positive samples that were negative according to the other two assays, showing that this assay can detect nonspecific binding. Overall, high titers in one assay were also high in the other two assays. Nevertheless, the Immundiagnostik and in-house assays were able to detect higher levels of IFX in sera samples, which may indicate the use of a more specific anti-human IgG antibody in the detection step in these assays than in Theradiag. The agreement between the three assays seemed to be more qualitative than quantitative. The three methodologies use the same ELISA sandwich principle, but there are some idiosyncratic differences that can explain the small discrepancies in quantitative evaluation: different detection limits and test sensitivity; reagent stability; different calibration standards and curve adjustment; and different sample dilution, manipulation and processing (e.g. different incubation times). Nevertheless, from a clinical point of view, the information given by the three assays (presence of positive/negative levels; low/therapeutic/high levels of the drug) showed acceptable interassay agreement. However, clinicians should be aware that changing drug level assays during patient follow up could induce errors in the interpretation of results and subsequent therapeutic strategies.

ADAs were evaluated using three methodologies: in-house AHLC, Immundiagnostik SFPE and Theradiag BE. These three assays have different methodological principles. The in-house AHLC is a sandwich ELISA that uses anti-human lambda chain conjugate antibody in the detection step, benefitting from IFX kappa chain exclusive composition [Kopylov et al. 2012]. The Theradiag
$\mathrm{BE}$ uses a double-antigen bridge: ADAs create a bridge between IFX immobilized on the plate and IFX enzyme-linked conjugate. The Immundiagnostik SFPE uses an initial acid buffer treatment to dissociate the IFX-ADA immune complexes and two IFX conjugates with different types of conjugates. Acidified samples are incubated with an IFX-biotin conjugate, which immobilizes ADAs to the plate, whilst an IFXperoxidase conjugate is used for detection.

A total of 79 samples of sera were compared using the three assays. The analytical approach showed the same moderate agreement for the three assays than the clinical approach. However, and from the analytical perspective, Theradiag was able to detect 37 positive ADAs, whereas from a clinical perspective only 24 patients were considered to be positive for ADAs. Conversely, the in-house assay detected almost the same number of ADApositive patients with the two approaches (34 for analytical versus 37 for clinical). The results obtained using a clinical perspective with the Theradiag kit suggest a high rate of false-negative outcomes. This high prevalence of false-negative outcomes with Theradiag was reported previously by other authors [Imaeda et al. 2012; Steenholdt et al. 2013]. Kopylov and colleagues reported that $\mathrm{BE}$ was unable to detect ADAs in the presence of IFX [Kopylov et al. 2012]. Our results showed that 22 out of 24 ADA-positive samples were IFX-negative. Only three patients showed a double-positive status with Theradiag, however neither was confirmed as IFX-positive in the in-house or Immundiagnostik assay. These samples were probably false positive for IFX. In fact, the disagreement of the in-house and Immundiagnostik assay with Theradiag for double-positive status (IFX+/ADAs+) was 100\%. Since Theradiag uses labeled IFX as the detection antibody, the presence of IFX may compete with the detection of the ADAs. On the other hand, the $\mathrm{BE}$ is unable to detect monovalent IgG4 ADAs, contributing to the false-negative results. Our results were consistent with these two statements and showed that samples positive for ADAs with the in-house and Immundiagnostik assays, but negative with Theradiag, one of two situations occurred: (i) sera samples were IFXpositive; or (ii) ADAs were IgG4 antibodies. The inability to detect antibodies in the presence of the drug is important as two recent studies have shown that patients with IFX levels $>3 \mu \mathrm{g} / \mathrm{ml}$ but with positive ADA have significantly higher levels of $\mathrm{C}$-reactive protein (CRP) and less mucosal 
healing [Casteele et al. 2015; Yanai et al. 2015], indicating a reduced control of inflammation mediated by these antibodies even when drug levels are adequate.

In order to understand the influence of drug presence on ADA detection, we designed an experiment using IFX-negative sera that were incubated with different concentrations of exogenous IFX. The in-house assay was slightly affected by $5 \mu \mathrm{g} / \mathrm{ml}$ exogenous infliximab but was able to detect antibodies up to $100 \mu \mathrm{g} / \mathrm{ml}$ of IFX. Kopylov and colleagues described the same drug concentration dependency for the AHLC assay [Kopylov et al. 2012]. However, our results permit us to define which concentration of IFX decrease the assay capacity to determine ADAs. The Immundiagnostik assay showed the best behavior in the presence of exogenous IFX. Interference was observed above $100 \mu \mathrm{g} / \mathrm{ml}$ of exogenous IFX but the assay was able to detect ADAs even at the higher concentration of $300 \mu \mathrm{g} / \mathrm{ml}$ of IFX. However, the results obtained in sera with high levels of ADAs were surprising and to the best of the authors' knowledge have not been reported previously. Even the Theradiag BE, which is widely described as being unable to detect antibodies in the presence of the drug, was able to identify ADA-positive samples in the presence of high levels of exogenous IFX. The results indicated that assays are not only limited by the levels of drug in the sera but also by the concentration of ADAs. These phenomena could be explained as follows: (i) in Theradiag, ADAs bind to all free drug in serum but there is still enough ADAs to bind to the plated IFX and bridge it to the conjugated one; (ii) in Immundiagnostik high levels of ADAs are most likely to diminish free IFX interference.

In summary, for IFX drug level determination, the three methodologies are equivalent, however the agreement between them seems to be more qualitative than quantitative. Regarding ADAs, despite being equally effective, the three assays show significant differences. Disagreement increased when samples had a double-positive or double-negative status, probably related to the specific limitations of each assay. The choice of cutoff to discriminate positive versus negative also enhances disagreement. This led us to define two different approaches with different cutoffs and present both evaluations. Clinical approach seems to highlight inabilities of the assays. In fact, Theradiag showed inability to detect positive ADA levels in samples with IFX $(<5 \mu \mathrm{g} / \mathrm{ml})$ or a high percentage of IgG4 ADAs. IgG4 ADAs are monovalent and unable to create a bridge with the labeled IFX used in detection step. In contrast, both the in-house assay and the Immundiagnostik assay are able to detect ADAs in the presence of IFX up to levels of $>100 \mu \mathrm{g} / \mathrm{ml}$ which conform with the therapeutic concentrations observed in patients receiving IFX. Unexpectedly, in samples with high levels of ADAs $(>25 \mu \mathrm{g} / \mathrm{ml})$, the presence of IFX was not as important and even Theradiag was able to detect antibodies. Nevertheless, Immundiagnostik was least affected by IFX, followed by the in-house assay. In conclusion, our results indicated that assays are not only limited by the levels of drug in the sera but also by the concentration of ADAs.

Clinicians must be aware when optimizing treatment that binary (IFX/ADAs) stratification of results as positive and negative can differ according to the assay used. There is a strong agreement between assays for IFX+/ADAs- and IFX-/ ADAs + status. The choice of assay will probably have little influence on therapeutic decisions to change the class of drug (IFX+/ADA-) or change anti-TNF $\alpha$ antibody (IFX-/ADAs + ). However, erroneous therapeutic decisions may occur when patients show double-negative or double-positive status, since agreement between assays is significantly lower in these circumstances. Treatment intensification (IFX-/ADAs-) and change of drug class or concomitant use of immunomodulators $(\mathrm{IFX}+/ \mathrm{ADAs}+)$ should take into account the fact that the results are assay dependent.

\section{Acknowledgements}

We thank Sandra Dias for her contribution as the GEDII coordinator.

Joana Afonso performed all laboratory experiments and participated in the data analysis, interpretation and drafting of the manuscript. Susana Lopes, Raquel Gonçalves, Paulo Caldeira, Paula Lago, Helena Tavares de Sousa, Jaime Ramos, Ana Rita Gonçalves, Paula Ministro, Isadora Rosa, Ana Isabel Vieira, Rosa Coelho, Patrícia Tavares, João-Bruno Soares, Diana Carvalho, Paula Sousa and Tânia Meira participated in patient recruitment and data collection. Filipa Silva Ferreira participated in data analysis and interpretation. Claudia Camila Dias performed the statistical analysis and participated in data analysis and interpretation. Yehuda Chowers and Shomron BenHorin revised the manuscript critically for important intellectual content. Fernando Magro conceived and designed the study, participated in 
data analysis, interpretation and drafting of the manuscript, and revised it critically for important intellectual content. All authors read and approved the final version of the manuscript.

\section{Funding}

This work was supported by the Portuguese Group of Studies in Inflammatory Bowel Disease (GEDII), Portugal, and partially by the European Regional Development Fund (ERDF); COMPETE (Operational Programme 'Thematic Factors of Competitiveness) and Fundação para a Ciência e a Tecnologia, Portugal (FCT) [grant number EXPL/IVC-PEC/1302/2013].

\section{Conflict of interest statement}

The authors declare that there is no conflict of interest.

\section{References}

Adedokun, O., Sandborn, W., Feagan, B., Rutgeerts, P., Xu, Z., Marano, C. et al. (2014) Association between serum concentration of infliximab and efficacy in adult patients with ulcerative colitis. Gastroenterology 147: 1296.

Baert, F., Noman, M., Vermeire, S., Van Assche, G., D'haens, G., Carbonez, A. et al. (2003) Influence of immunogenicity on the long-term efficacy of infliximab in Crohn's disease. $N$ Engl F Med 348: 601-608.

Ben-Horin, S., Yavzori, M., Katz, L., Kopylov, U., Picard, O., Fudim, E. et al. (2011) The immunogenic part of infliximab is the $\mathrm{F}\left(\mathrm{Ab}^{\prime}\right)(2)$, but measuring antibodies to the intact infliximab molecule is more clinically useful. Gut 60: 41-48.

Bendtzen, K. (2013) Personalized medicine: theranostics (therapeutics diagnostics) essential for rational use of tumor necrosis factor-alpha antagonists. Discov Med 83: 201-211.

Bendtzen, K. and Svenson, M. (2011) Detection and Quantification of Antibodies to Bipharmaceuticals: Practical and Applied. Chichester: John Wiley \& Sons Ltd.

Casteele, N., Buurman, D., Sturkenboom, M., Kleibeuker, J., Vermeire, S., Rispens, T. et al. (2012) Detection of infliximab levels and anti-infliximab antibodies: a comparison of three different assays. Aliment Pharmacol Therapeut 36: 765-771.

Casteele, N., Khanna, R., Levesque, B., Stitt, L., Zou, G. Singh, S. et al. (2015) The relationship between infliximab concentrations, antibodies to infliximab and disease activity in Crohn's disease. Gut 64: 1539-1545.

Visit SAGE journals onlin http://tag.sagepub.com

@SAGE journals determination of anti-infliximab antibodies in inflammatory bowel disease. F Gastroenterol 47: 136-143.

Kopylov, U., Mazor, Y., Yavzori, M., Fudim, E., Katz, L. Coscas, D. et al. (2012) Clinical utility of antihuman lambda chain-based enzyme-linked immunosorbent assay (ELISA) versus double antigen ELISA for the detection of anti-infliximab antibodies. Inflamm Bowel Dis 18: 1628-1633.

Landis, J. and Koch, G. (1977) Measurement of observer agreement for categorical data. Biometrics 33: 159-174.

Roblin, X., Rinaudo, M., Del Tedesco, E., Phelip, J., Genin, C., Peyrin-Biroulet, L. et al. (2014) Development of an algorithm incorporating pharmacokinetics of adalimumab in inflammatory bowel diseases. Am F Gastroenterol 109: 1250-1256.

Steenholdt, C. (2013) Use of infliximab and antiinfliximab antibody measurements to evaluate and optimize efficacy and safety of infliximab maintenance therapy in Crohn's disease. Danish Med F 60(4): B4616.

Steenholdt, C., Ainsworth, M., Tovey, M., Klausen, T., Thomsen, O., Brynskov, J. et al. (2013) Comparison of techniques for monitoring infliximab and antibodies against infliximab in Crohn's disease. Ther Drug Monitor 35: 530-538.

Steenholdt, C., Bendtzen, K., Brynskov, J., Thomsen, O. and Ainsworth, M. (2014a) Clinical implications of measuring drug and anti-drug antibodies by different assays when optimizing infliximab treatment failure in Crohn's disease: post hoc analysis of a randomized controlled trial. Am F Gastroenterol 109: 1055-1064.

Steenholdt, C., Brynskov, J., Thomsen, O., Munck, L., Fallingborg, J., Christensen, L. et al. (2014b) Individualised therapy is more cost-effective than dose intensification in patients with Crohn's Disease who lose response to anti-TNF treatment: a randomised, controlled trial. Gut 63: 919-927.

Ungar, B., Anafy, A., Yanai, H., Ron, Y., Yavzori, M., Picard, O. et al. (2015) Significance of low level infliximab in the absence of anti-infliximab antibodies. World F Gastroenterol 21: 1907-1914.

Van Schouwenburg, P., Kruithof, S., Wolbink, G., Wouters, D. and Rispens, T. (2016) Using monoclonal antibodies as an international standard for the measurement of anti-adalimumab antibodies. $\mathcal{F}$ Pharm Biomed Anal 120: 198-201.

Yanai, H. and Hanauer, S. (2011) Assessing response and loss of response to biological therapies in IBD. Am $\mathcal{F}$ Gastroenterol 106: 685-698.

Yanai, H., Lichtenstein, L., Assa, A., Mazor, Y., Weiss, B., Levine, A. et al. (2015) Levels of drug and antidrug antibodies are associated with outcome of interventions after loss of response to infliximab or adalimumab. Clin Gastroenterol Hepatol 13: 522-530. 